\title{
A nine-level hybrid current source inverter using common- emitter topology and inductor-cell
}

\author{
Suroso $^{1}$, Daru Tri Nugroho ${ }^{2}$, Toshihiko Noguchi ${ }^{3}$ \\ ${ }^{1,2}$ Department of Electrical Engineering, Jenderal Soedirman University, Indonesia \\ ${ }^{3}$ Department of Electrical and Electronics Engineering, Shizuoka University, Japan
}

\begin{tabular}{l}
\hline Article Info \\
\hline Article history: \\
Received Jul 31, 2018 \\
Revised Nov 11, 2018 \\
Accepted Feb 6, 2019 \\
\hline
\end{tabular}

Keywords:

Common-emitter inverter Current-source converter Photovoltaics

Power grid

\begin{abstract}
A different circuit structure of nine-level current source power inverter is presented and discussed in this manuscript. The proposed topology is based on the common-emitter inverter topology equipped with an inductor-cell circuit. The common-emitter inverter works as the main inverter circuits delivering a three-level AC current waveform. The inductor-cell circuit produces the intermediate output current levels for nine-level current output waveform. Proportional integral current controller was applied to regulate the current streaming thru the inductor-cell. Multi triangular carrier signals based sinusoidal pulse width modulation method was utilized to obtain a lower waveform distortion. The proposed nine-level inverter circuit was tested and examined. The test results verified that the new nine-level inverter circuit worked well producing a nine-level current waveform with less lowfrequency harmonic components.
\end{abstract}

Copyright (c) 2019 Institute of Advanced Engineering and Science. All rights reserved.

\section{Corresponding Author:}

Suroso,

Department of Electrical Engineering, Jenderal Soedirman University,

Jl. Mayjen Sungkono km. 5, Purbalingga, Jawa Tengah, Indonesia.

Email: suroso.te.unsoed@gmail.com

\section{INTRODUCTION}

Basically, electrical power can be clasified into two main forms, i.e. DC and AC power. In many cases, the DC power is simpler than the AC power because of its characteristics. Transmitting of DC power is also simpler than the $\mathrm{AC}$ power [1]. There are not phenomena such as skin effect, oscilation, or voltage unbalance between phases. Furthermore, there is no reactance property of the conductor in the DC power system. The DC power may be generated by a DC power generation system such as DC generator machine, photovoltaic module, and fuel cell system. However, currently most of power loads need AC voltage or AC current even in some loads the supplied AC power must be processed into DC using additional power converter circuits [2-4].

The power converters are required to proceed the DC power to be AC power, and vice versa. The converter used to alter the DC power into AC power is called power inverter. In the power inverter, the frequency, magnitude, and phase angle values of $\mathrm{AC}$ voltage and current can be regulated as required. Mainly, there are two categories of power inverters, i.e. voltage source inverter and current source one [5-8]. The first type proceeds a DC input voltage become a certain AC output voltage. The DC input bus uses capacitors to obtain a stable DC input voltage. Hence, short circuit condition is prohibited in this type of inverter, as it will cause large current that will damage the inverter circuits $[9,10]$. In the second inverter type, the power inverter transforms the DC input current into a desired AC current. This inverter utilizes power inductor to generate a stable DC input current. Different with the voltage source type inverter, in this inverter type an open circuit condition is forbidden, because a large voltage change will happen in the inductor that may destroy the circuits $[11,12]$. 
In order to obtain higher power of inverter circuits, a multilevel inverter has been introduced. This multilevel inverter generates a multistep AC output waveform from a single or multi DC input power [1316]. When the input power is a single or multiple DC voltage sources and the output is a multistep AC voltage, the power inverter is called as multilevel voltage source inverter $[17,18]$. In contrast, when the DC input power is a single or multiple DC currents and the output waveform is a multistep AC current, the inverter is called as multilevel current source inverter circuits [19-22]. Instead of higher power capability, a better output waveform can be produced using multilevel inverter circuits [23].

Reference [24] and [25] proposed a basic three-level current source inverter called as three-level common-emitter current source inverter (CECSI), because of its common-emitter configuration. This threelevel inverter circuits is figured in Figure 1. Four unidirectional controlled switches, i.e. $T_{1}, T_{2}, T_{3}$ and $T_{4}$, with common-emitter connection are required in this circuit to deliver a three-level output current waveform using two DC current sources. To generate a ninelevel current waveform, reference [26] discussed the use of inductor cells and a sole three-level CECSI as displayed in Figure 2. Twelve controlled switches were needed in this nine-level inverter circuits. Another approach was proposed in reference [27] and [28], where multi DC current modules are connected to the basic three-level common-emitter inverter.

This research develop a nine level inverter circuits using combination of inductor-cell and DC current module circuits connected to the main three-level common emitter circuits. Using this new nine-level inverter, switching devices and the power supplies of driving circuits could be simplified. Basic principle operation of the circuits was discussed. The nine-level inverter circuits was tested and examined using computer simulations.

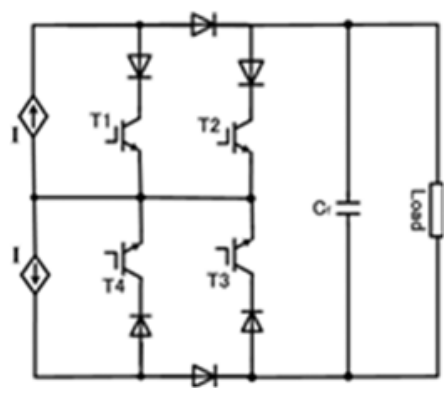

Figure 1. Basic three-level CECSI [24-30]

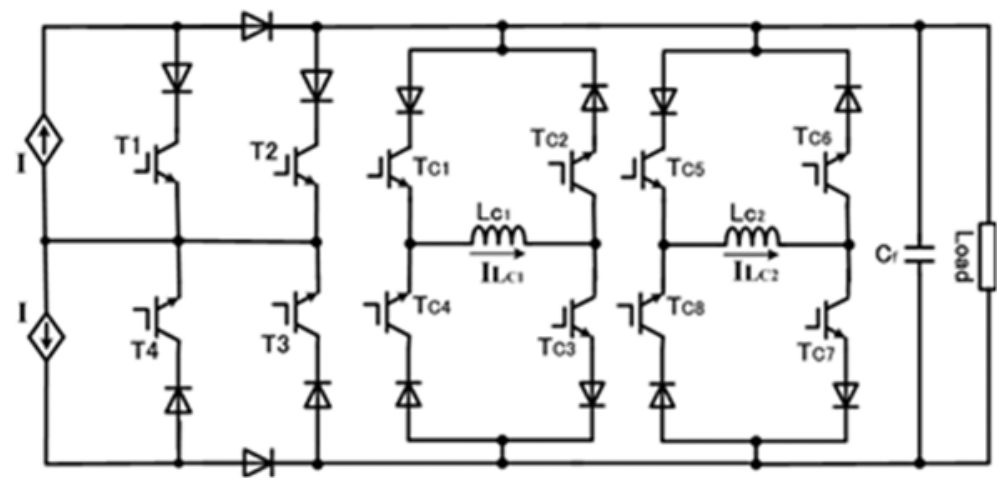

Figure 2. Traditional nine-level inverter [26]

\section{PROPOSED NINE-LEVEL INVERTER CIRCUITS}

Based on the basic three-level common emitter circuit configuration, a new nine-level inverter circuits is presented in Figure 3. The circuits consist of ten controlled switches as shown in this figure. The controlled switch is connected in series with a diode to perform a single directional current controlled power switch. The main inverter circuits constructed by six controlled switches connected in common-emitter configuration, hence a simpler driving circuits can be applied in this circuits.

The inductor cell circuits consist of four controlled switches, i.e. $T_{C 1}, T_{C 2}, T_{C 3}$ and $T_{C 4}$. The power inductor is placed across this cell. Using the basic charging and discharging properties of this inductor cell, a 
ninelevel current waveform will be generated [26]. The basic operations of the circuits are shown in Table 1. Furthermore, Figure 4 is the inverter circuit including the DC current control circuits with DC input inductor $\mathrm{L}_{1}, \mathrm{~L}_{2}, \mathrm{~L}_{3}$ and $\mathrm{L}_{4}$ and controlled switches $\mathrm{T}_{\mathrm{L} 1}, \mathrm{~T}_{\mathrm{L} 2}, \mathrm{~T}_{\mathrm{L} 3}$ and $\mathrm{T}_{\mathrm{L} 4}$. These dc inductors and switches are utilized to generate the DC currents for inverter.

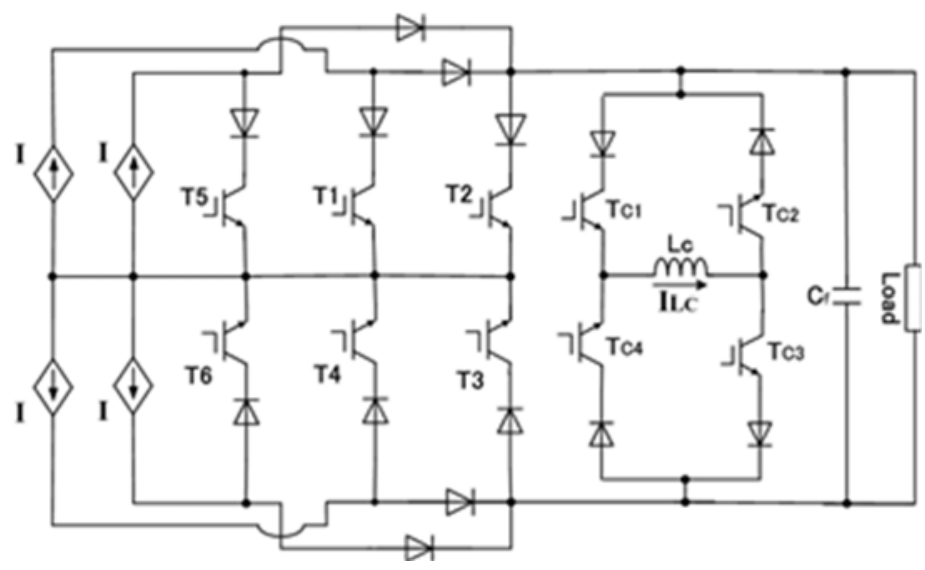

Figure 3. Proposed nine-level hybrid inverter

Table 1. Operation modes of the inverter

\begin{tabular}{cccccccccccc}
\hline Modes & $\mathrm{T}_{1}$ & $\mathrm{~T}_{2}$ & $\mathrm{~T}_{3}$ & $\mathrm{~T}_{4}$ & $\mathrm{~T}_{5}$ & $\mathrm{~T}_{6}$ & $\mathrm{~T}_{\mathrm{C} 1}$ & $\mathrm{~T}_{\mathrm{C} 2}$ & $\mathrm{~T}_{\mathrm{C} 3}$ & $\mathrm{~T}_{\mathrm{C} 4}$ & $\mathrm{I}_{\mathrm{PWM}}$ \\
\hline 1 & 0 & 0 & 1 & 1 & 0 & 1 & 1 & 1 & 0 & 0 & $+2 \mathrm{I}$ \\
2 & 0 & 0 & 1 & 1 & 0 & 1 & 0 & 1 & 0 & 1 & $+3 / 2 \mathrm{I}$ \\
3 & 0 & 0 & 1 & 1 & 1 & 1 & 0 & 0 & 1 & 1 & $+\mathrm{I}$ \\
4 & 0 & 0 & 1 & 1 & 1 & 1 & 1 & 0 & 1 & 0 & $+\mathrm{I} / 2$ \\
5 & 1 & 1 & 1 & 1 & 1 & 1 & 1 & 1 & 0 & 0 & 0 \\
6 & 1 & 1 & 0 & 0 & 1 & 1 & 0 & 1 & 0 & 1 & $-\mathrm{I} / 2$ \\
7 & 1 & 1 & 0 & 0 & 1 & 1 & 1 & 1 & 0 & 0 & $-\mathrm{I}$ \\
8 & 1 & 1 & 0 & 0 & 1 & 1 & 1 & 0 & 1 & 0 & $-3 \mathrm{I} / 2$ \\
9 & 1 & 1 & 0 & 0 & 1 & 0 & 0 & 0 & 1 & 1 & $-2 \mathrm{I}$ \\
\hline
\end{tabular}

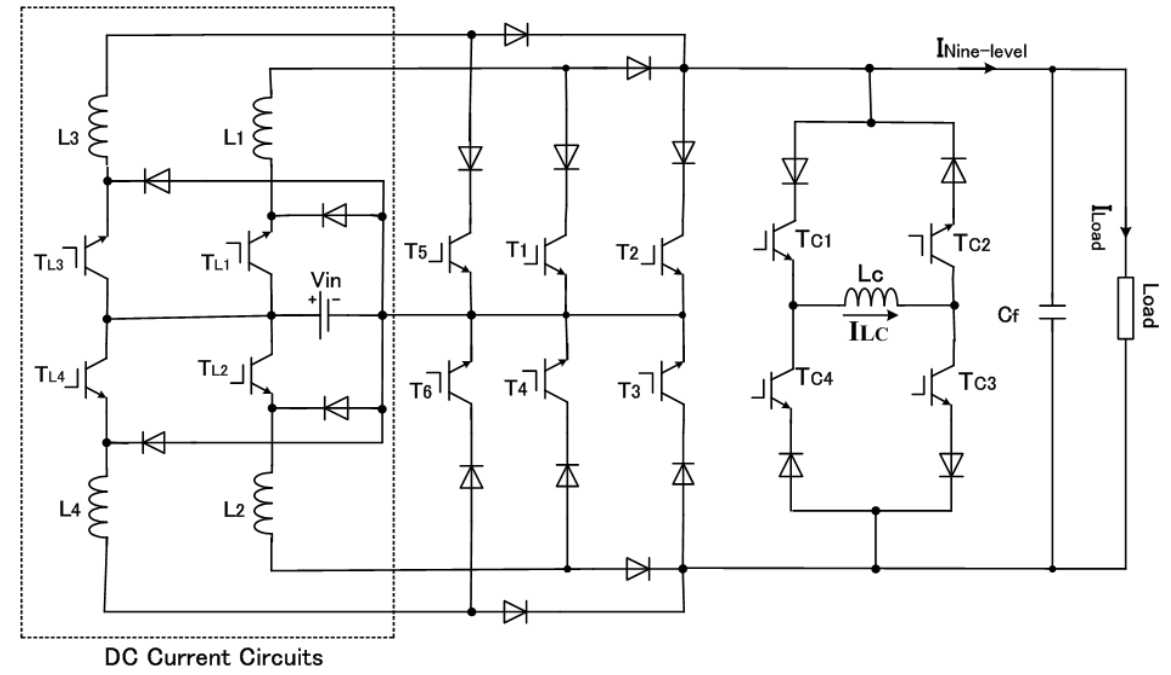

Figure 4. Nine-level inverter with dc current circuits 
To regulate the current in the inductor, a proportional integral (PI) current controller is applied as presented in Figure 5. The amplitude of inductor-cell current was determined as a half of magnitude of the main dc input currents. This inductor-cell circuit function to create the intermediate levels of the nine-level current waveform. Furthermore, carrier based sinusoidal modulation was applied to generate a PWM AC current waveform with less harmonic distortion as shown in Figure 6. Eight triangular carriers were used. Each carrier has the same frequency but with different offset value. These carriers were modulated by a single sinusoidal signal to generate PWM driving signals of inverter power circuits.

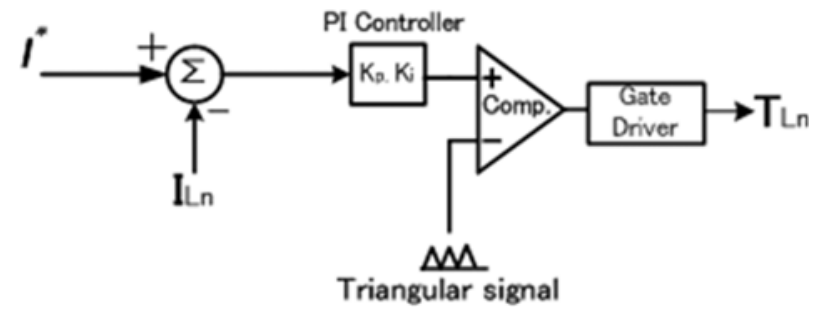

Figure 5. Current controller [27, 30]

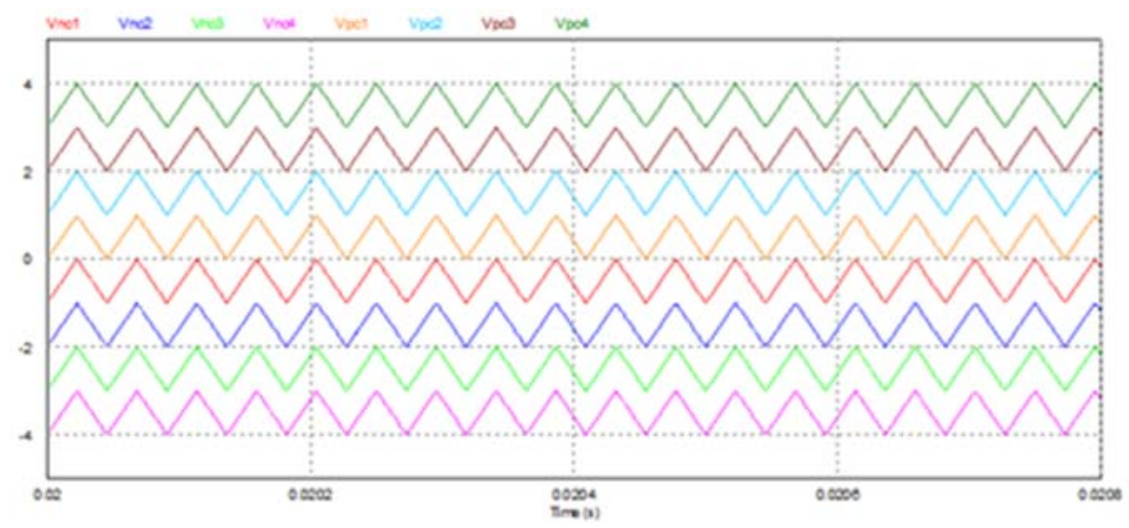

Figure 6. Modulation method [18, 27]

\section{TEST RESULTS AND ANALYSIS}

To test the basic operation and characteristic of the new nine-level inverter circuits, some computer simulations were performed using software of Power PSIM. The test parameters of the proposed new ninelevel inverter circuits are presented in Table 2. The enormity of dc current sources is set to be 5 ampere. Four dc input current circuits were connected to the inverter circuits as shown in Figure 4. A small inductor 0.3 $\mathrm{mH}$ was used for the inductor-cell circuits. The frequency of triangular carriers is $22 \mathrm{kHz}$ to avoid the noise caused by the switching operation. Using high switching frequency, a smaller output capacitor filter $\left(\mathrm{C}_{\mathrm{f}}\right)$ size can be achieved. In this experiment, the filter capacitor was $5 \mu \mathrm{F}$. The inverter was connected to an electrical load, i.e. power resistor $12 \Omega$ and power inductor $1.2 \mathrm{mH}$ connected in series.

Figure 7 is the simulation output figuring the waveforms of nine-level output current, current thru electrical load, and the capacitor filter current. Harmonic spectra of this nine-level current waveform is presented in Figure 8. The highest amplitude of the low harmonic order in this figure is the $3^{\text {rd }}$ harmonic component. Its amplitude is $0.5 \%$, only. The harmonics of PWM current flowed by way of the capacitor filter as current $\mathrm{I}_{\mathrm{Cf}}$. As a result, the current in the power load was a sinusoidal waveform. Furthermore, Figure 9 presents the dc currents in the inductors $\mathrm{L}_{1}, \mathrm{~L}_{2}, \mathrm{~L}_{3}, \mathrm{~L}_{4}$ and $\mathrm{L}_{\mathrm{c}}$. The same magnitudes of current were achieved. The magnitude of inductor cell current is half of these inductor currents, as it functions to perform the intermediate level currents of nine-level current. Finaly, Figure 10 depicts the transient test results of the inverter, when the command current was changed. High speed response was achieved for the current transient waveforms of inverter circuits. 
Table 2. Parameters of inverter circuits

\begin{tabular}{ccc}
\hline No. & Parameters & Values \\
\hline 1 & DC current & $5 \mathrm{~A}$ \\
2 & Inductor cell & $0.3 \mathrm{mH}$ \\
3 & Triangular frequency & $22 \mathrm{kHz}$ \\
4 & Fundamental frequency & $50 \mathrm{~Hz}$ \\
5 & Capacitor filter & $5 \mu \mathrm{F}$ \\
6 & Power load & $12 \Omega, 1.2 \mathrm{mH}$ \\
\hline
\end{tabular}

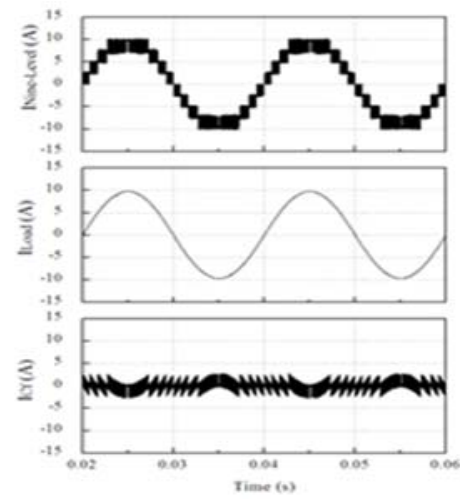

Figure 7. Measured waveforms of nine-level output current, load current and capafitor filter current.

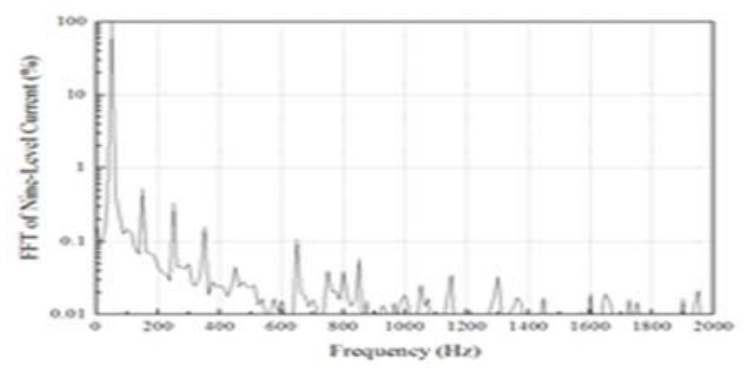

(b)

(a)

Figure 8. Harmonic profiles of the nine-level current waveform

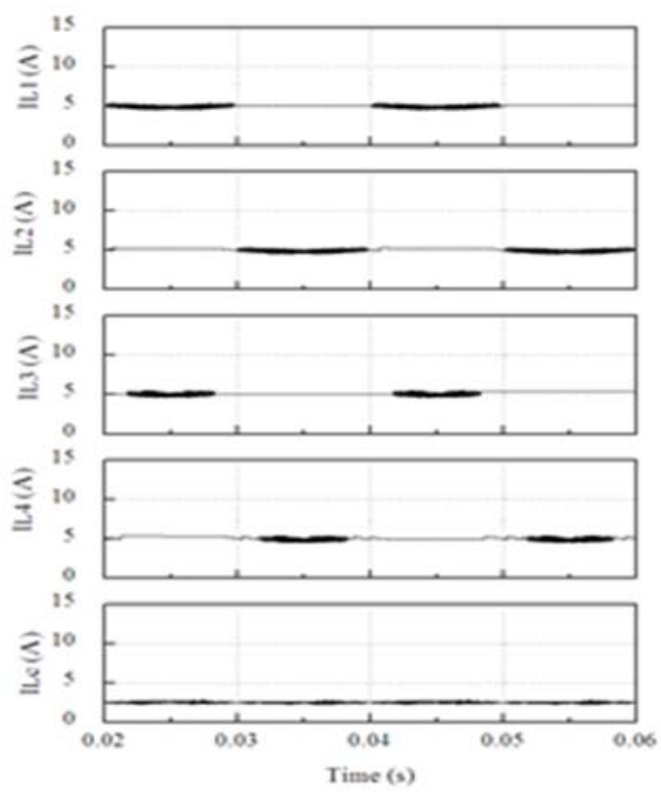

Figure 9. Waveforms of inductor currents 


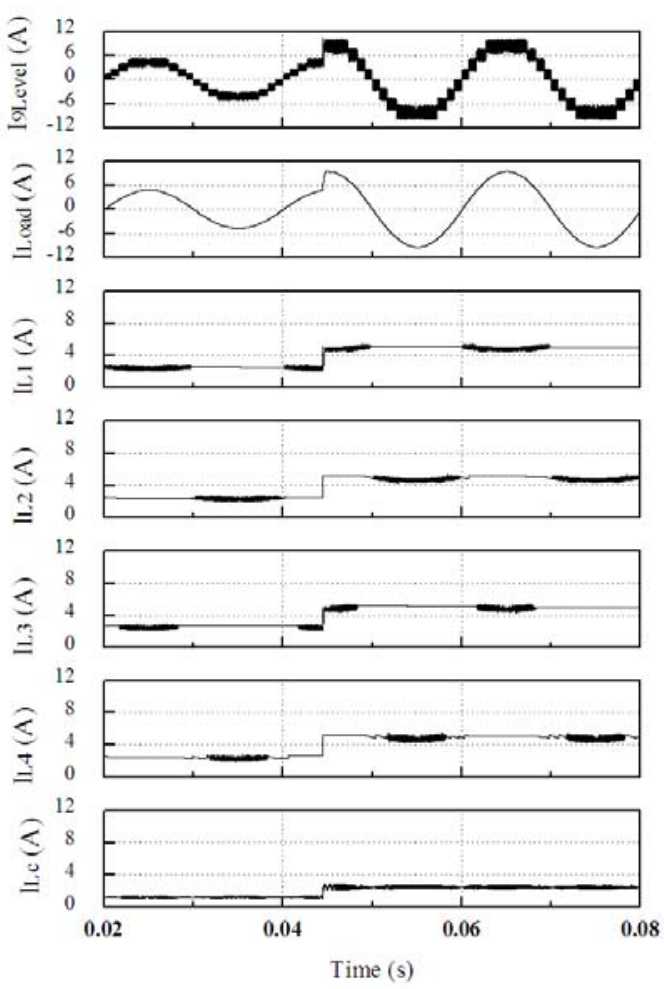

Figure 10. Transient current waveforms

\section{CONCLUSION}

A nine-level current-source power inverter circuits using common-emitter inverter and inductor-cell circuits was presented and examined in this research paper. The new inverter circuit produced a nine level PWM output current waveform from the dc input currents with low harmonic components. Using small capacitor filter, a sinusoidal load current was obtained. Proportional current controller worked regulating a stable inductor cell current to generate a balanced intermediate levels of nine-level current waveform. A simpler nine-level inverter circuit and more stable inductor currents can be achieved in this new inverter.

\section{REFERENCES}

[1] K. Kurohane, A. Uehara, T. Senjyu, A. Yona, N. Urasaki, T. Funabashi, and C. Kim, "Control strategy for a distributed DC power system with renewable energy", Renewble Energy, vol. 36, issue 1, pp. 42-49, January 2011.

[2] J. M. Carrasco, L. G. Franquelo, J. T. Bialasiewicz, E. Galván, R. C. Portillo Guisado, Ma. Ángeles Martín Prats, J. Ignacio León, and N. Moreno-Alfonso, "Power-electronic systems for the grid integration of renewable energy sources: a survey", IEEE Transactions on Industrial Electronics, vol. 53, no.4, p.p. 1002-1016, August 2006.

[3] P. G. Barbosa, H. A. C. Braga, M. C. Barbosa, and E. C. Teixeria, "Boost current multilevel inverter and its application on single phase grid connected photovoltaic system," IEEE Transaction on Power Electronics, vol. 21, no. 4, p.p. 1116-1124, July 2006.

[4] F. Blaabjerg, Z. Chen, and S. B. Kjaer, "Power electronics as efficient interface in dispersed power generation system”, IEEE Transactions on Power Electronics, vol. 19, no. 5, p.p. 1184-1194, September 2004.

[5] Z H. Bai, and Z. C. Zhang, "Conformation of multilevel current source converter topologies using the duality principle," IEEE Transactions on Power Electronics, vol. 23, p.p. 2260-2267, September 2008.

[6] B. P. McGrath, and D. G. Holmes, "Natural current balancing of multi-cell current source inverter," IEEE Transactions on Power Electronics, vol. 23, no. 3, p.p. 1239-1246, May 2008.

[7] S. Kwak, and H. A. Toliyat, "Multilevel converter topology using two types of current-source inverters," IEEE Transactions on Inductry Applications, vol. 42, no. 6, p.p. 1558-1564, November/December 2006.

[8] Suroso and T. Noguchi, "Multilevel current waveform generation using inductor cells and H-bridge current source inverter", IEEE Transactions on Power Electronics, vol. 27, issue. 3, p.p. 1090-1098, 2012.

[9] D. H. Lee, and J. Ohn, "A simple and direct dead-time effect compensation scheme in PWM-VSI", IEEE Transactions on Industry Application, vol. 50, no. 5, pp. 3017-3025, September 2014. 
[10] L. Chen, and F. Z. Peng, "Dead-time elimination for voltage source inverters", IEEE Transactions on Power Electronics, vol. 23, no. 2, pp. 574-580, March 2008.

[11] Y. Geng, R. Deng, W. Dong, K. Wang, H. Liu, and X. Wu, "An overlap-time compensation method for currentsource space-vector PWM inverters," IEEE Transactions on Power Electronics, Volume 33, Issue 4, p.p. 31923203, April 2018.

[12] T. Halkosaari, K. Kuusela, and H. Tuusa, "Effect of non-idealities on the performance of the 3-phase current source PWM converter", proc. of 2001 IEEE 32 ${ }^{\text {nd }}$ Annual Power Electronics Specialists Conference, p.p. 654-659, 2001.

[13] N. Vazquez, H. Lopez, C. Hernandez, E. Vazquez, R. Osorio, and J. Arau, "A different multilevel current source inverter", IEEE Transactions on Industrial Electronics, vo. 57, p.p. 2623 - 2632, August 2010.

[14] F. L. M. Antunes, A. C. Braga, and I. Barbi, "Application of a generalized current multilevel cell to current source inverters," IEEE Transactions on Power Electronics," vol. 46, no.1, p.p. 31-38, February 1999.

[15] Y. L. Kameswari, and O. C. Sekhar, "Fuzzy logic controlled harmonic suppressor in cascaded multilevel inverter", International Journal of Power Electronics and Drive Systems (IJPEDS), p.p. 303-310, 2016.

[16] Suroso, D. T. Nugroho, A. N. Azis, T. Noguchi, "Simplified five-level voltage source inverter with level-phaseshifted carriers based modulation technique", Indonesian Journal of Electrical Engineering and Computer Science, vol. 13, no. 2, 2019, pp. 461-468, 2019.

[17] J. Rodiguez, J. S. Lai, and F. Z. Peng, "Multilevel inverter: a survey of topologies, controls, and application," IEEE Transactions on Industrial Electronics," vol. 49, no. 4, p.p. 724-738, August 2002.

[18] B. Wu, High Power Converters and AC Drives. Piscataway, NJ: IEEE Press, 2006, ch. 10.

[19] Suroso and T. Noguchi, "A single-phase multilevel current-source converter using H-bridge and DC current modules", International Journal of Power Electronics and Drive System (IJPEDS), vol. 2, no. 4, p.p. 165-172, 2014.

[20] Suroso, and T. Noguchi. "Novel H-bridge multilevel current-source PWM inverter with inductor-cells", Conference Proceedings IPEC, p.p. 445-450, 2010.

[21] Suroso and T. Noguchi, "Five-level common-emitter inverter using reverse-blocking IGBTs", TELKOMNIKA, vol. 10, no. 1, p.p. 25-32, 2012.

[22] D. Tamilarasi, and T. S. Sivakumaran, "Analysis of symmetrical and asymmetrical current source multilevel inverter", Circuits and Systems, p.p. 3469-3484, 2016.

[23] Suroso, A. N. Aziz, and T. Noguchi, "Five-level PWM inverter with a single DC power source for DC-AC power conversion", International Journal of Power Electronics and Drive Systems (IJPEDS), vol. 8, p.p. 1230-1237, September 2017.

[24] Suroso and T. Noguchi, "A new three-level current-source PWM inverter and its application for grid connected power conditioner", Energy Conversion and Management, vol. 51, issue 7, p.p. 1491-1499, 2010.

[25] Suroso, D. T. Nugroho, and Winasis, "A three-level common-emitter current source inverter with reduced device count", 4th International Conference on Information Technology, Computer, and Electrical Engineering (ICITACEE), p.p. 77-80, 2017.

[26] T. Noguchi, and Suroso, "New multilevel current-source PWM inverter with full-bridge inductor cells", IEEJ Transactions on Industry Applications, vol. 130, no. 6, p.p. 808-815, 2010.

[27] Suroso, and T. Noguchi, "Common-emitter topology of multilevel current-Source pulse width modulation inverter with chopper based DC-current sources", IET Power Electronics, vol. 4, issue 7, p.p. 759-766, 2011.

[28] T. Noguchi, and Suroso, "Review of novel multilevel current-source inverters with H-bridge and common-emitter based topologies", IEEE Energy Conversion Congress and Exposition, p.p. 4006-4011, 2010.

[29] K. Iwaya, and T. Noguchi, "Novel current-source multilevel inverter driven by single gate drive power supply", Electrical Engineering in Japan, vol. 166, no. 2, p.p. 10-16, 2009.

[30] Suroso, D.T. Nugroho and Winasis, "Three-level common-emitter current source power inverter with simplified dc current source generation”, Journal of Engineering Science and Technology, vol. 13, no.2, p.p. 4027-4038, 2018.

Int J Pow Elec \& Dri Syst, Vol. 10, No. 2, June 2019: 852 - 859 


\section{BIBLIOGRAPHY OF AUTHORS}
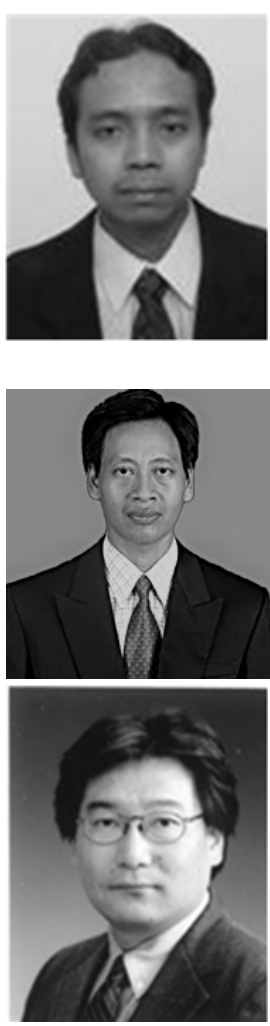

Suroso received the B. Eng. degree in electrical engineering, from Gadjah Mada University, Indonesia in 2001, and the M. Eng. degree in electrical and electronics engineering from Nagaoka University of Technology, Japan in 2008. He was a research student at electrical engineering department, Tokyo University, Japan from 2005 to 2006. He earned the Ph.D degree in energy and environment engineering department, Nagaoka University of Technology, Japan in 2011.He was a visiting researcher at electrical and electronics engineering department, Shizuoka University, Japan from 2009 to 2011. Currently, He is an associate professor at department of electrical engineering, Jenderal Soedirman University, Purwokerto, Jawa Tengah, Indonesia.His research interest includes static power converters, and its application in renewable energy conversion and distributed power generation.

Daru Tri Nugroho received bachelor (B.Eng.) degree in electrical engineering from Institute Teknologi Sepuluh November, Surabaya, Indonesia and M.Eng. degree in electrical engineering from Universitas Indonesia. Currently $\mathrm{He}$ is a lecturer in Electrical Engineering Department, Jenderal Soedirman University. His research interests are power system and renewable energy.

Toshihiko Noguchi was born in 1959. He received the B. Eng. degree in electrical engineering from Nagoya Institute of Technology, Nagoya, Japan, and the M. Eng. and D. Eng. degrees in electrical and electronics systems engineering from Nagaoka University of Technology, Nagaoka, Japan, in 1982, 1986, 1996, respectively. In 1982, he joined Toshiba Corporation, Tokyo, Japan. He was a Lecturer at Gifu National College of Technology, Gifu, Japan, from 1991 to 1993 and a Research Associate in electrical and electronics systems engineering at Nagaoka University of Technology from 1994 to 1995. He was an Associate Professor at Nagaoka University of Technology from 1996 to 2009. He has been a Professor at Shizuoka University since 2009 . His research interests are static power converters and motor drives. Dr. Noguchi is a Member of the IEE-Japan and a Senior Member of the IEEE. 